\title{
Hydrodynamics of cotton filtration drying
}

\author{
Volodymyr Atamanyuk $^{1}$, Zoriana Gnativ ${ }^{1}$ Dauren Dzhanabaiev ${ }^{2}$, Alisher Khusanov ${ }^{2}$ \\ 1. Department of Chemical Engineering, Lviv Polytechnic National University, UKRAINE, Lviv, 9 St. Yura square, \\ Building 9, E-mail: atamanyuk@ukr.net \\ 2. Department of Production machines and equipment, Auezov South Kazakhstan State University, \\ KAZAKHSTAN, Shymkent, Tauke khan avenue, 5, E-mail: husanov_a @ mail.ru
}

The movement of the gas flow through the porous structure of the material is a problem of hydrodynamics. The intensity of heat and mass transfer during the drying process determines the rate of thermal agent movement relatively to the elements of the porous layer. In this paper, the experimental results regarding the pressure loss in a layer of cotton fiber during filtration drying are presented. Under the action of pressure difference the effect of the cotton fiber layer height on the porosity, equivalent diameter, through which the thermal agent is filtered, the specific surface area and the pressure loss was analytically determined.

Keywords - cotton fiber, hydrodynamics, filtration drying, criterion dependencies.

\section{Introduction}

It is known [1-4] that cotton, namely cotton fiber, is widely used in various industries: chemical, automotive, aviation, for the production of wool and materials for industrial and household use. Cotton fiber is also used as new, non-traditional material, such as reinforcing composites, geotextiles, individual absorbents, etc. [5]. Since the 1940s, the world consumption of cotton has been steadily increasing by $2 \%$ per year [6]. Approximately 20 million tonnes of raw cotton is produced worldwide each year. As a result, approximately 6,5-7 million tonnes of cotton fiber is produced. When processing raw cotton in order to obtain more efficient and high quality fiber, its moisture content should be within $8-9 \%$, and this demand requires drying of freshly picked cotton [7]. Therefore, modernization of cotton processing is extremely important for the development of Kazakhstan's economy.

According to its structure, raw cotton is a heterogeneous material, which consists of three main components - the cotton fiber itself, the peel and the seed kernel. Cotton seeds are used to produce oils, lubricants, soaps, glycerin, stearin, ethyl and methyl alcohols, citric and acetic acids and many other products [8]. In general, raw cotton is a colloidal capillary-porous material containing all kinds of moisture $[9,10]$, the removal of which consumes a considerable amount of energy.

Cotton fiber is a thermolabile material and contains mainly bound moisture. It is important to choose the optimum drying mode to prevent fiber break and reduction of fiber length [11]. The analysis of literature data [9-12] makes it possible to conclude that there is no comprehensive and systematic approach to intensify the drying processes of wet cotton fiber.

Object and research methods. The object of the experimental studies was freshly harvested cotton fiber. The chemical composition is: $95-98 \%$ of cellulose, about $1 \%$ of minerals, the rest is natural waxes, fats and proteins. JSM-6490LV raster electron microscope was used to determine the average size of cotton villi.

More than 100 samples of randomly selected cotton fibers were analyzed. The cotton fiber under study (Fig. 1) consists of thin villi with a length of $25-45 \mathrm{~mm}$, an average width of 24.8 $\mu \mathrm{m}(170 \mathrm{mtex})$ and an average thickness of $4.51 \mu \mathrm{m}$. The cotton fiber density is $1520 \mathrm{~kg} / \mathrm{m} 3$. 

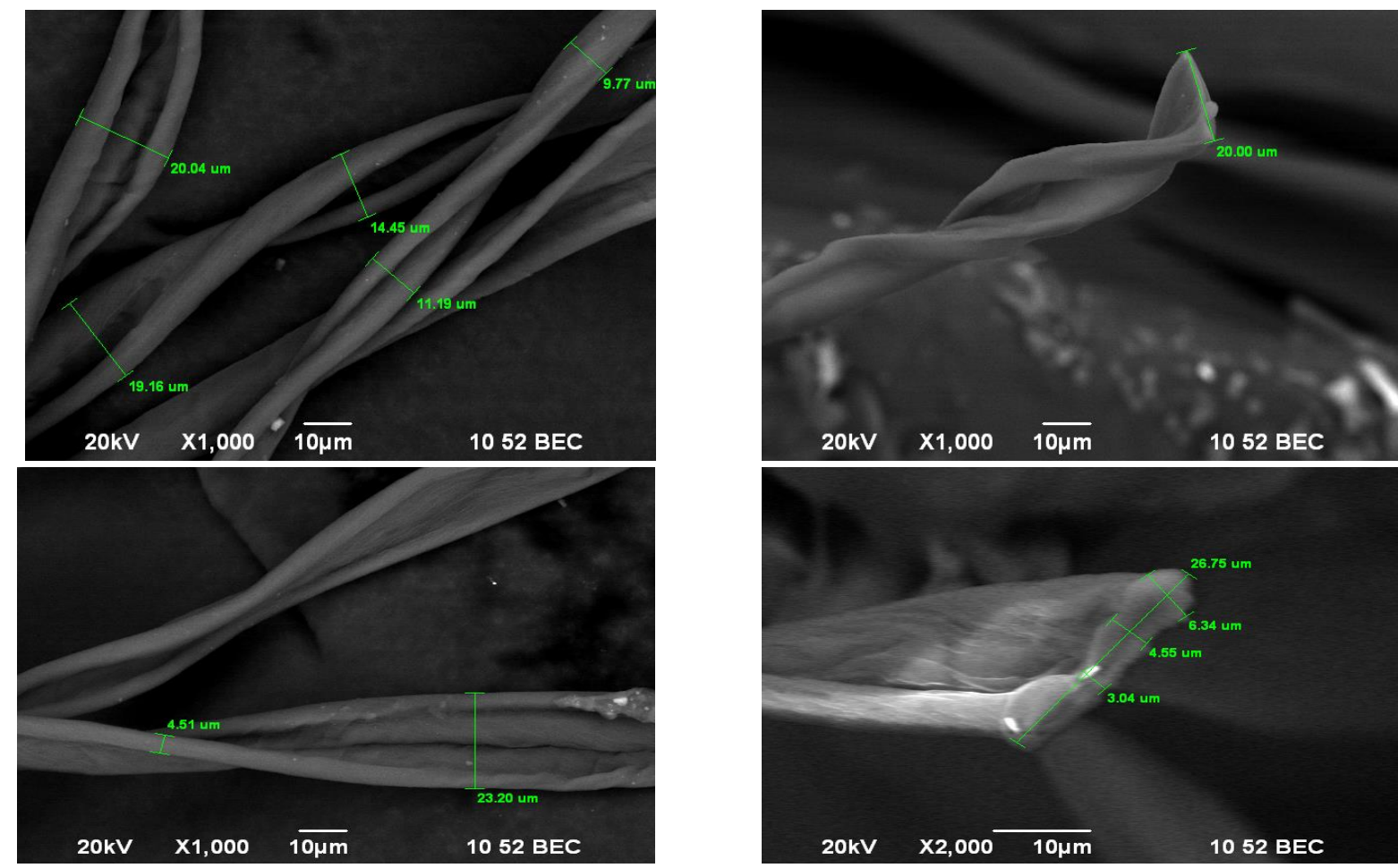

Fig. 1. Images of individual villi of cotton fiber (x1000)

\section{The experimental part.}

All experiments were performed with corresponding aliquots of cotton fiber. Taking into account that the moisture content of natural cotton fiber is negligible $(0.08-0.12 \mathrm{~kg} \mathrm{H} 2 \mathrm{O} / \mathrm{kg}$ dry.mat. ) and the moisture is mainly bound one, for the gas flow temperature $\mathrm{T}=293 \mathrm{~K}$ and relative humidity $\varphi=60 \%$ its evaporation will also be negligible (the time of the experiment was $90-120 \mathrm{~s}$, the weight loss of the sample during the experiment was less than $0.2 \%$ ). So, the influence of moisture evaporation on the pressure loss was neglected.

$\Delta P, \mathrm{kPa}$

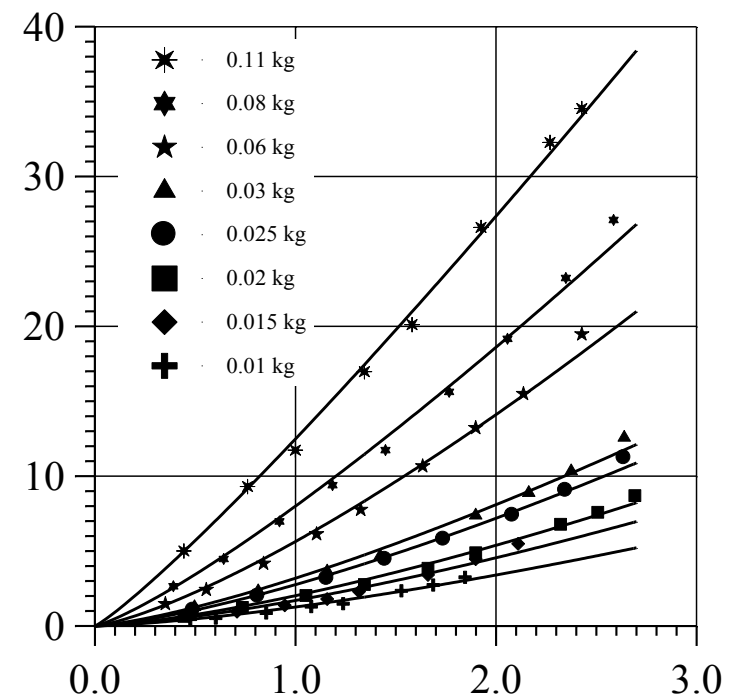

$v_{0}, \mathrm{~m} / \mathrm{s}$

Fig. 2. The dependence of the pressure loss in the cotton fiber layer on the fictitious filtration rate of the thermal agent at different weight of the samples $\varepsilon, \mathrm{m}^{3} / \mathrm{m}^{3}$

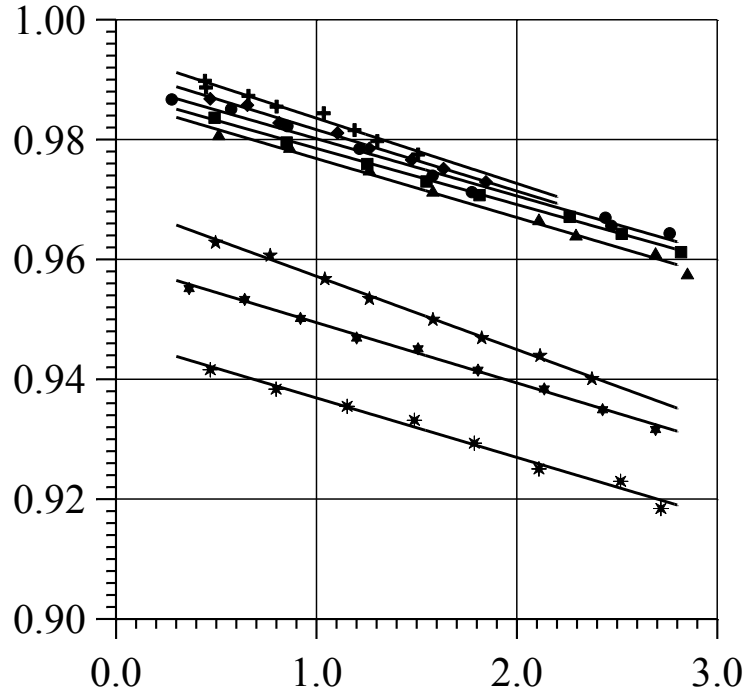

$v_{0}, \mathrm{~m} / \mathrm{s}$

Fig. 3. The dependence of the cotton fiber layer porosity on the fictitious filtration rate of the thermal agent (symbols are the same as for Fig. 2) 
Experimental results of the thermal agent filtration through a layer of cotton fiber of different weights are presented in the form of functional dependence $\Delta P=f\left(v_{0}\right)$ and are shown in Fig. 2.

The analysis of Fig. 2 shows that the curves are parabolic, that is, the pressure loss in the cotton fiber layer is affected by both viscous and inertial components. The change in the layer porosity depending on the fictitious filtration rate of the thermal agent $\varepsilon=f\left(v_{0}\right)$ is shown in Fig. 3.

\section{Conclusion.}

Obtained dimensionless dependence allows to predict the energy costs necessary to create the pressure difference (under the same hydrodynamic conditions); it is suitable during the design of new drying equipment. The dependence can be used when technological parameters need to be changed, for example, the height of the cotton fiber layer or the filtration rate of the thermal agent. The error between theoretically calculated values and experimental data does not exceed $14.2 \%$, which is quite acceptable for the design of new drying equipment.

\section{References}

[1] Kale, R., Bansal, P. and Gorade, V., 2017. Extraction of Microcrystalline Cellulose from Cotton Sliver and Its Comparison with Commercial Microcrystalline Cellulose. Journal of Polymers and the Environment, 26(1), pp.355-364.

[2] Zeng, L., Zhao, S. and He, M., 2018. Macroscale porous carbonized polydopaminemodified cotton textile for application as electrode in microbial fuel cells. Journal of Power Sources, 376, pp.33-40.

[3] Wedin, H., Niit, E., Mansoor, Z., Kristinsdottir, A., de la Motte, H., Jönsson, C., Östlund, $\AA$. and Lindgren, C., 2018. Preparation of Viscose Fibres Stripped of Reactive Dyes and Wrinkle-Free Crosslinked Cotton Textile Finish. Journal of Polymers and the Environment, 26(9), pp.3603-3612.

[4] Cui, L., Shi, S., Hou, W., Yan, Z. and Dan, J., 2018. Hydrolysis and carbonization mechanism of cotton fibers in subcritical water. New Carbon Materials, 33(3), pp.245-251.

[5] L.H.C.D., S., 2000. Estudo da Secagem de Materiais Texteis. Ph.D. Maringaa.

[6] Azhimetova, G., 2011. Mirovoy opyt i obzor razvitiya khlopkovodstva v Kazakhstane. Sovremennyye problemy nauki i obrazovaniya, 1, pp.53-58.

[7] Shaykhov, E. and Normukhamedov, N., 1990. Pakhtachilik. Tashkent: Mekhnat, p.284.

[8] Lv, N., Wang, X., Peng, S., Luo, L. and Zhou, R., 2018. Superhydrophobic/superoleophilic cotton-oil absorbent: preparation and its application in oil/water separation. RSC Advances, 8(53), pp.30257-30264.

[9] Ibrogimov, K., Alimardonov, K., Zul'fanov, S. and Badalov, A., 2007. Termodinamicheskiye kharakteristiki protsessa degidratatsii khlopka-syrtsa. Tekhnologiya tekstil'noy promyshlennosti, 4, pp.19-22.

[10] Boltaboyev, S. and Parpiyev, A., 1980. Sushka khlopka-syrtsa. Tashkent: Ukituvchi.

[11] Egamberdiyev, A., Ibragimov, S. and Amanturdiyev, A., 2009. Gŭza selektsiyasi, uruggchiligi va biologiyasi. Tashkent: Nauka, p.128.

[12] Azhimetova, G., 2011. Mirovoy opyt i obzor razvitiya khlopkovodstva v Kazakhstane. Sovremennyye problemy nauki i obrazovaniya, 1, pp.53-58. 